\title{
THE ODONTOCETE COMMUNITY AND ITS ENVIRONMENT IN THE SOUTHWESTERN GULF OF CALIFORNIA ${ }^{1}$
}

\author{
Christian J. Salvadeo ${ }^{2,3, *}$, Alejandro Gómez-Gallardo U. ${ }^{2}$, Daniel Lluch-Belda ${ }^{3}$ and Jorge Urbán R. ${ }^{2}$
}

\begin{abstract}
Aвstract: Community structure is a function of the number of species, their relative abundance and the characteristics of the dominant, common and rare species that are part of it. It also can be described by changes in its physical and biological environment. The aim of the present work is to describe the odontocete community, its temporal changes and the relationship with environmental variability and food availability in the southwestern Gulf of California (GC). Information was obtained from 21 sampling trips from September 2003 to March 2006 between La Paz Bay and Loreto, with a sampling effort of $8769.1 \mathrm{~km}$. We recorded the presence, location and other biological parameters of odontocete sightings. Data on environmental variability was obtained from satellite images of sea surface temperature and chlorophyll concentration, and food availability from published reports. A total of 30201 odontocete cetaceans were recorded from 353 sightings, belonging to 10 different species. We observed a temporal lag between the peaks in productivity and an increased presence of odontocete species. The community structure showed a seasonal change in the abundance of the dominant (Tursiops truncatus and Delphinus sp.) and common species (Globicephala macrorhynchus and Kogia sp.), as well as by the absence or presence of scarce (Physeter macrocephalus and Orcinus orca) and rare species (Pseudorca crassidens and Lagenorhynchus obliquidens). This seasonal community change is in agreement with the known seasonal movements of its main prey inside the GC, which, in turn, is related to seasonal environmental variation. We observed that the community structure was dominated by fish-eating species during the temperate season and responded to the increased presence and aggregation of sardines (Sardinops sagax caerulea) in the southern GC, whereas the warm season was dominated by squid-eating species and related to the increased presence and aggregation of the jumbo squid (Dosidicus gigas) in the GC's west coast.
\end{abstract}

RESUMEN La estructura comunitaria depende del número de especies, sus abundancias y las características de las especies dominantes, comunes y raras que la conforman; a su vez, ésta puede cambiar como consecuencia de variaciones naturales de su ambiente. El objetivo del presente trabajo es describir la comunidad de odontocetos, sus cambios temporales y su relación con la variabilidad ambiental y disponibilidad de presas en el suroeste del Golfo de California (GC). La información de la comunidad se obtuvo de 21 muestreos en el área de Bahía de La Paz y Loreto realizados entre septiembre-2003 y marzo-2006, con un esfuerzo de 8769.1km; la variabilidad ambiental superficial se obtuvo a partir de imágenes de satélite (temperatura y concentración de clorofila) y la disponibilidad de alimento se infirió de reportes y publicaciones científicas. Se observaron un total de 30201 organismos durante 353 avistamientos, identificándose 10 especies. Se observó un desfase temporal entre los picos de productividad y una mayor presencia de odontocetos, así como un dinamismo estacional en la estructura de la comunidad debido a cambios en las abundancias de las especies dominantes (Tursiops truncatus y Delphinus sp.) y comunes (Globicephala macrorhynchus y Kogia sp.), así como por la presencia o ausencia de las especies escasas (Physeter macrocephalus y Orcinus orca) y raras (Pseudorca crassidens y Lagenorhynchus obliquidens). Estos cambios coinciden con los movimientos estacionales de presas potenciales en aguas del Golfo. Durante la estación templada y más productiva (invierno-primavera) se observa una dominancia de especies ictiófagas, coincidiendo con una mayor disponibilidad de sardinas en el área, debido a que la sardina (Sardinops sagax caerulea) del GC se distribuye más sureña; mientras que durante la estación cálida y menos productiva se observó una dominancia de especies teutófagas, coincidiendo con una mayor presencia y agregación de calamares (Dosidicus gigas) en la costa oeste del Golfo.

KEYwORDs: cetacean ecology, prey availability, seasonal environmental changes, Gulf of California.

\section{Introduction}

A biological community is a set of populations of different species that interact in a determined space and time (Begon et al., 1999). Community structure is a function of the number of species, their relative abundances and the characteristics of dominant, common and rare species that are part of it. It can also be described by changes in its physical and biological environment (Krebs, 2001). To satisfy their metabolic and reproductive requirements cetaceans, like other mammals, undertake movements between areas (Reeves et al., 2002). Such movements determine their distribution and residency patterns, which affect the structure of the community by changes at different spatial and temporal scales (Flores-Ramírez et al., 1996). These distribution and residency patterns can be interpreted as the manifestation of the environmental preference, including food availability, as well as behavioral patterns (reproductive, foraging, etc.), presence of other species (competition and predation) and the dispersal capacity of the species (Begon et al., 1999; Krebs, 2001).

The Gulf of California (GC) is an interesting region for the study of biological communities due to its geographic position and oceanographic conditions. The environmental heterogeneity, high productivity and oceanographic processes that occur inside the GC, determine the presence of a great biological diversity, including cetaceans (Urbán et al., 2005). The aim of the present work is to describe the odontocete community

\footnotetext{
${ }^{1}$ Received on 25 April 2009. Accepted on 21 April 2010. Managed by Maritza Sepúlveda.

${ }^{2}$ Universidad Autónoma de Baja California Sur, Carretera al Sur km 5.5, C.P. 23080 La Paz, B.C.S. México.

${ }^{3}$ Centro Interdisciplinario de Ciencias Marinas, IPN. A.P. 592. C.P. 23000 La Paz, B.C.S. México.

* Corresponding author, e-mail: chsalvadeo@yahoo.com.mx.
} 
in the southwestern part of the GC and its relationship with environmental variability and food availability.

\section{Environmental variability of the study area}

The GC is considered a semi-enclosed sea from an oceanographic and meteorological viewpoint (LluchCota, 2000). The study area (Figure 1) is located in the southwestern part of the GC. It is a bathymetrically complex area, with the presence of basins, seamounts and several volcanic islands. The continental shelf is irregular and narrow (no more than $5 \mathrm{~km}$ ), except in some areas like off Loreto, San Jose Channel and the southern part of La Paz Bay. The hydrography is complex, with a great spatial and temporal variability, as a consequence of the oceanographic and meteorological events that occur inside the GC. Atmospheric forcing over the GC is markedly seasonal. Two seasons are well defined: a highly productive temperate period (winter-spring) and a warm, less productive season (summer-autumn) (Lluch-Cota et al., 2007). North-northwesterly winds prevail during the temperate season, promoting upwelling along the GC's eastern coast (Maluf, 1983; Soto-Mardones et al., 1999). Such upwelling fertilizes the entire GC through a system of eddies that carry enriched waters from the eastern to the western coast (Beier, 1997; Navarro-Olache et al., 2004). During the warm season, weak south-southeasterly winds become predominant, and weak upwelling occurs along the peninsular coast (Maluf, 1983; Soto-Mardones et al., 1999). Oligotrophic waters from the North Equatorial Pacific also enter into the GC at this time (Jiménez-Illescas et al., 1997), intensifying the stratification of the water column, while intense radiation and weak winds reduce the thickness of the mixed layer (ObesoNieblas, 2003). The latter results in a marked drop in net productivity at most GC localities during the warm season. Only at the Midriff Islands the high productivity levels are maintained year-long by tidally-forced mixing (Santamaria del Angel et al., 1994).

\section{Prey Availability in the GC}

Small pelagic fish are a key component of the GC ecosystem; they are consumed by seabirds, marine mammals, and other fish (Velarde et al., 2004). The most abundant species in a regional context is the Pacific sardine (Sardinops sagax caerulea), which has its main center of distribution near the Midriff Islands (Figure 1; Lluch-Belda et al., 1995). During the warm season, sardines restrict their distribution to the highly productive waters near the midriff islands, whereas during the temperate season the expansion of productive waters allows sardine schools move to the southern GC and spawn (Lluch-Belda et al., 1986; Hammann et al., 1998).

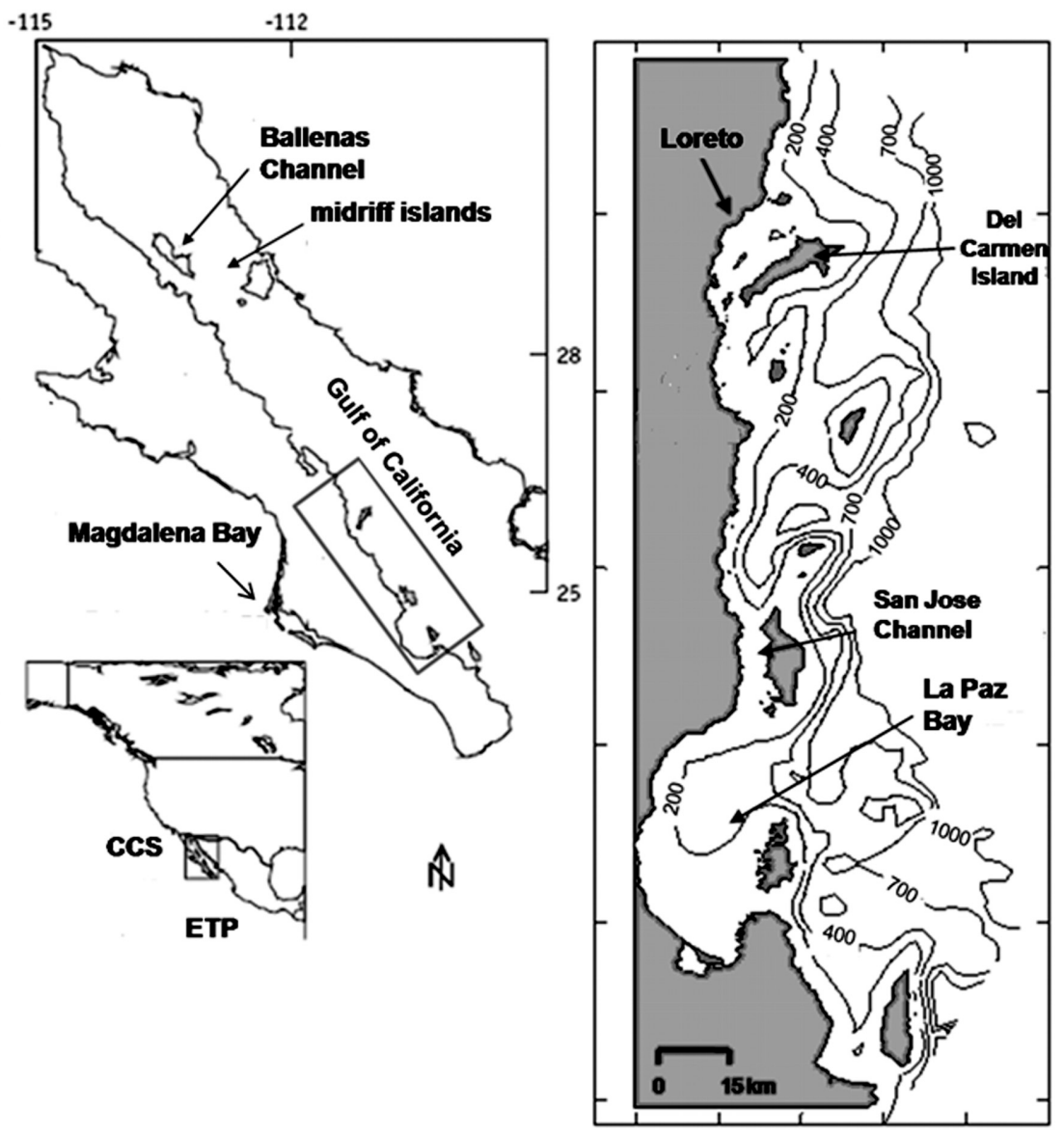

Figure 1. Study area; ETP: Eastern Tropical Pacific; CCS: California Current System. 
Squid. On a global scale, $80 \%$ of odontocete species regularly include cephalopods in their diet (Clarke, 1996). The jumbo squid (Dosidicus gigas) is the most abundant squid inside the GC and presents a complex migratory behavior: during the warm season they concentrate along the GC's western coast, taking advantage of the upwelling area to feed, whereas during the temperate season some of them move to the GC's eastern coast, where the upwelling takes place, while others concentrate in the central and deeper areas of the GC (Klett, 1996; BritoCastillo et al., 2000; Morales-Bojórquez et al., 2001; Markaida and Sosa-Nishizaki, 2003).

\section{Material and Methods}

\section{Data recording and analysis}

Odontocete sightings were obtained from 21 sampling trips during September 2003 to March 2006, with a sampling effort of $8769.1 \mathrm{~km}$ (Table 1, Figure 2). We used two types of boats: one with $7 \mathrm{~m}$ in length and $1 \mathrm{~m}$ in height (12 sampling trips), and a second one with $15 \mathrm{~m}$ in length, $4 \mathrm{~m}$ in width and $6 \mathrm{~m}$ in height (9 sampling trips). In each season at least two trips were made with both types of boats. During each sampling trip we followed a consistent but non-random search method, in which the boat ran in a straight line at cruising speed (11kt) following a predetermined track (parallel to the coast and sometimes around of some islands) trying to cover most of the study area between Bay of La Paz and Loreto, with less than Beaufort 3 wind scale conditions (higher conditions significantly reduce the capacity of observers to detect cetaceans; Kiszka et al., 2007). The trips were recorded with GPS, with observers located one at the front and two at each side of the boat for cetacean searching with the aid of binoculars (7x50 power). Effort stops, of about two minutes, were made every 30 minutes, for observer rotation. During time of search effort, when a cetacean was sighted we recorded date, hour, species (to the lowest possible taxon), location, number of animals (average between observers), behavior and association with other marine species (birds, fishes, mammals and turtles).

The data recorded from each platform (boat type) were standardized for the analysis using the distance to the visible horizon of each one. This was calculated using

Table 1. Total numbers of sampling trips and kilometers traveled for each type of boat and season (temperate: $\mathrm{T}$; warm: $\mathrm{W}$ ) from September 2003 to March 2006.

\begin{tabular}{lcccc}
\hline \hline & \multicolumn{2}{c}{ SAMPLING TRIPS } & \multicolumn{2}{c}{ EFFORT $(\mathrm{km})$} \\
& LARGE & SMALL & LARGE & SMALL \\
\hline \hline W 03 & 1 & 1 & 608.9 & 254.3 \\
T 04 & 1 & 3 & 877.2 & 591.1 \\
W 04 & 1 & 2 & 883.5 & 576.5 \\
T 05 & 2 & 3 & 1055.7 & 999.9 \\
W 05 & 2 & 2 & 1070.9 & 287.8 \\
T 06 & 2 & 1 & 1385.8 & 177.5 \\
Total & 9 & 12 & 5882.0 & 2887.1 \\
\hline \hline
\end{tabular}

Equation 1 (Bowditch, 1995), and assumed that the proportion of effort for each platform was similar to the proportion between their distances to the visible horizon (Equation 2). This proportion was calculated (Equation 3) and the effort of the small boat was standardized as half of the effort of the large boat $\left(D_{\beta} / D_{b}=0.5\right)$.

$$
\begin{gathered}
D=2.07 \sqrt{ } h(\text { Equation } 1) \\
E_{p} / E_{b}=D_{p} / D_{b} \text { (Equation 2) } \\
E_{p}=\left(D_{p} / D_{b}\right) E_{b} \text { (Equation 3) }
\end{gathered}
$$

Where $D=$ distance to the visible horizon in nautical miles from small boat $\left(D_{p}\right)$ and large boat $\left(D_{b}\right)$, respectively; $h=$ height of the searching platform for the small boat $(h p=1 \mathrm{~m})$ and large boat $(h b=4 \mathrm{~m})$, respectively; and $E=$ effort for the small boat $\left(E_{p}\right)$, and large boat $\left(E_{b}\right)$ (both in $\mathrm{km}$ ).

To characterize the environmental variability of the study area, we used monthly averages of sea surface temperature (SST) and sea surface chlorophyll concentration (Chl) from Aqua-MODIS and SeaWiFS satellite images, respectively, in HDF format (http:/ / oceancolor.gsfc.nasa.gov), at $4 \mathrm{~km}$ of spatial resolution. We used MATLAB® program to handle the images and calculate the monthly averages of SST and Chl.
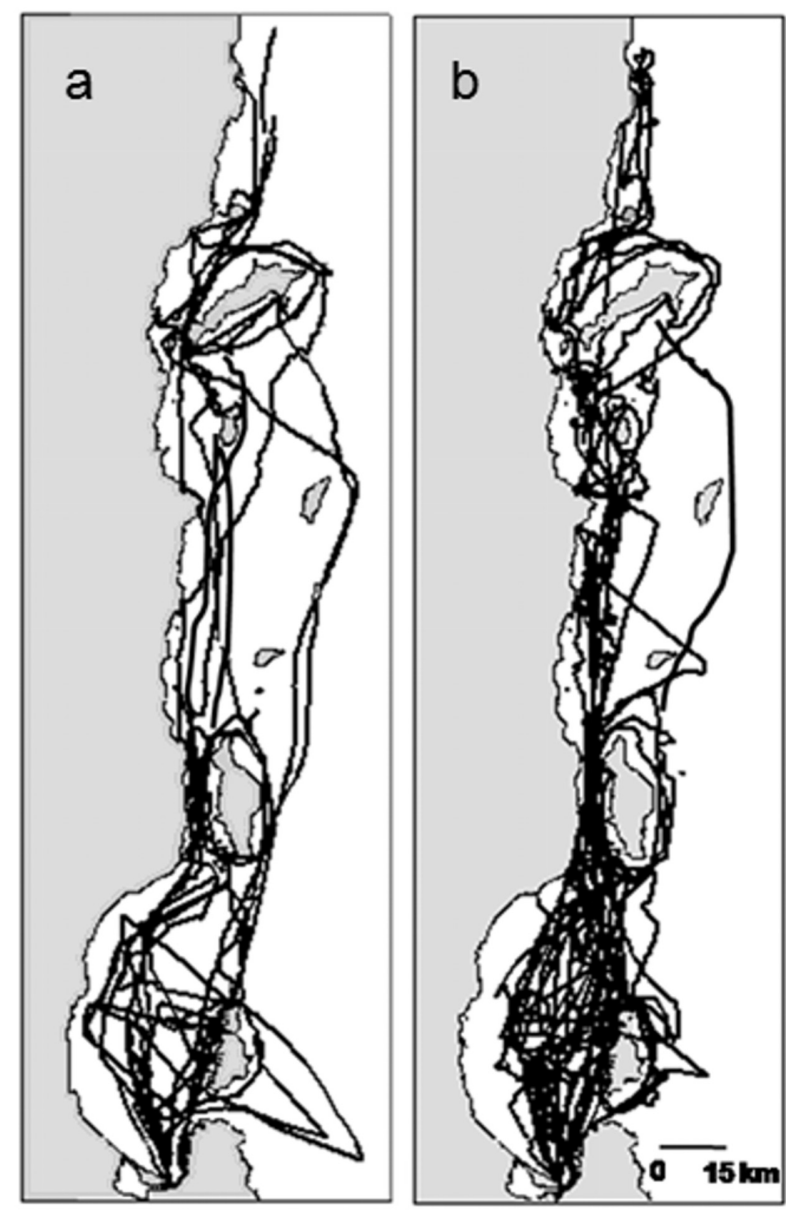

Figure 2. Sample trips: a) warm season (summer-autumn) and b) temperate season (winter-spring) 
We determined the seasonality from the differences between the monthly SST and the total average of SST for the entire period, considering two seasons: temperate (monthly SST < total average) and warm (monthly SST $>$ total average).

To evaluate the community structure, we calculated an abundance index (percentage of total for the entire study period) in three different ways: from the sightings; from the number of animals; and from estimates of biomass (number of animals * body biomass) contributed by each species. Since the dominance of every species depends on the expressions of the abundance index that was considered, we decided to calculate, for each species, the Importance Value Index (IVI; Muller-Dombois and Ellenberg, 1974); which allows the integration of all of these indexes into a single one. This method is commonly used in vegetation ecology, and here it was modified to evaluate species dominance. The IVI was calculated as the sum of the percentage of sightings, the number of animals and the biomass of each species from the respective total. As an approach of quantify their seasonal and interannual occurrence inside the area, we sum to the IVI the percentage of seasons that each species was present (three warm and three temperate seasons). From the IVI value we sort the species in four categories: dominant (IVI > 200), common (200 > IVI > 100), scarce $(100>$ IVI $>20)$ and rare $($ IVI $<20)$.

The SST and Chl 'standard year' for the study period (SSTsp and Chlsp, respectively) were calculated using a least-squares-adjustment to assess temporal changes in the community structure. Additionally, the Chl 'standard year' for the last 10 years was calculated to compare with the Chlsp. The monthly averages of abundance index for dominant species were calculated and compared with the SSTsp and Chlsp. As we observed in the monthly series of the 'standard year' a temporal lag between Chlsp and relative biomass $(\mathrm{kg} / \mathrm{km})$ from the three most dominant species, a Spearman's cross-correlation analysis with onemonth lag was applied.

Then we calculated and compared for each species the seasonal (temperate and warm season) relative abundance index (sightings $/ \mathrm{km}$, animals $/ \mathrm{km}$ and biomass $/ \mathrm{km}$ ) and their seasonal dominance (IVI). In addition, we calculated and compared the seasonal community diversity and equity from Simpson's index (calculated from biomass). This index expresses the probability that two individuals randomly taken from a sample are of the same species. It is calculated as $\lambda=\sum p i^{2}$, where $p i$ is the proportion of the species I from the total sample. Simpson's index was plotted to observe seasonal patterns, and an ANOVA was applied to evaluate differences in the seasonal diversity.

\section{Results}

The average of SST in the area for the study period was $24.8^{\circ} \mathrm{C}$, with a minimum of $19^{\circ} \mathrm{C}$ (during the temperate season) and a maximum of $31^{\circ} \mathrm{C}$ (during the warm season). The Chl showed an average of $0.856 \mathrm{mg} / \mathrm{m}^{3}$, with a minimum of $0.19 \mathrm{mg} / \mathrm{m}^{3}$ and a maximum of $1.718 \mathrm{mg} /$ $\mathrm{m}^{3}$. In the monthly average of SSTsp and Chlsp for the study area (Figure 3a), it is possible to observe the marked seasonality mentioned above, with a temperate, high productivity season (winter and spring) and a warm, low productivity season (summer and autumn).

During the entire study period, 30201 individuals were recorded from 353 sightings, belonging to 10 different species and a category of unidentified dolphins (Tables 2 and 3). The dominant species were the common dolphin (Delphinus sp.) and the bottlenose dolphin (Tursiops truncatus), the common species were the shortfinned pilot whale (Globicephala macrorhynchus) and the pygmy and dwarf sperm whales (Kogia sima and K. breviceps.). The scarce species were the sperm whale (Physeter macrocephalus) and the killer whale (Orcinus orca). The rare species were the false killer whale (Pseudorca crassidens) and the pacific white side dolphin (Lagenorhynchus obliquidens).

The community structure showed a temporal dynamism (Figures 3 and 4) due to changes in the abundance and occurrence of the dominant and common species, as well as by the absence or presence of scarce and rare species. The standard year showed a temporal lag between Chlsp peaks and the major presence of dominant species (Figure 3). It is approximately one month for the common dolphins (Figure $3 \mathrm{~b} ; \mathrm{r}=0.77, p=0.006$ ). This time lag pattern may also be observed when the FloresRamirez et al. (1996) data is matched with the Chl monthly average for the past 10 years in the area (Figure $3 c$ ), although, for common and bottlenose dolphins the temporal lag is about three months.

The community structure showed seasonal variability in the dominance and diversity (Figures $4 \mathrm{a}$ and $4 \mathrm{~b}$ ) in response to the changes in population numbers (abundance and occurrence) of dominant and common species, as well as the presence or absence of scarce and rare species (Figures $4 \mathrm{c}$ and $4 \mathrm{~d}$ ). The Simpson diversity index showed a co-variation with the equity index, but this did not show significant differences between seasons $(\mathrm{F}=4.359, p=0.105)$. However, the warm season was the most diverse due to its greater equity (Figure $4 \mathrm{~b}$ ), a result of a better distribution of species abundances (Figure $4 \mathrm{~d}$ ). During the temperate season there was an increase in the presence and abundance of common dolphins (Figures 4a, 4c, and 4d). In addition, if we look at the sightings with feeding behavior during this season, 64\% were dominated by common dolphins (Table 4 ), and $40 \%$ were observed in association with birds. In contrast, during the warm season there was an increase in the presence and dominance of bottlenose dolphins and short-finned pilot whales (Figures 4a, 4c, and $4 \mathrm{~d}$ ). Some $58 \%$ of sightings observed with feeding behavior during this season (Table 4) were dominated by squid-eating species like short-finned pilot whales, sperm whales, false killer whales and bottlenose dolphins, with no seabirds associated. 

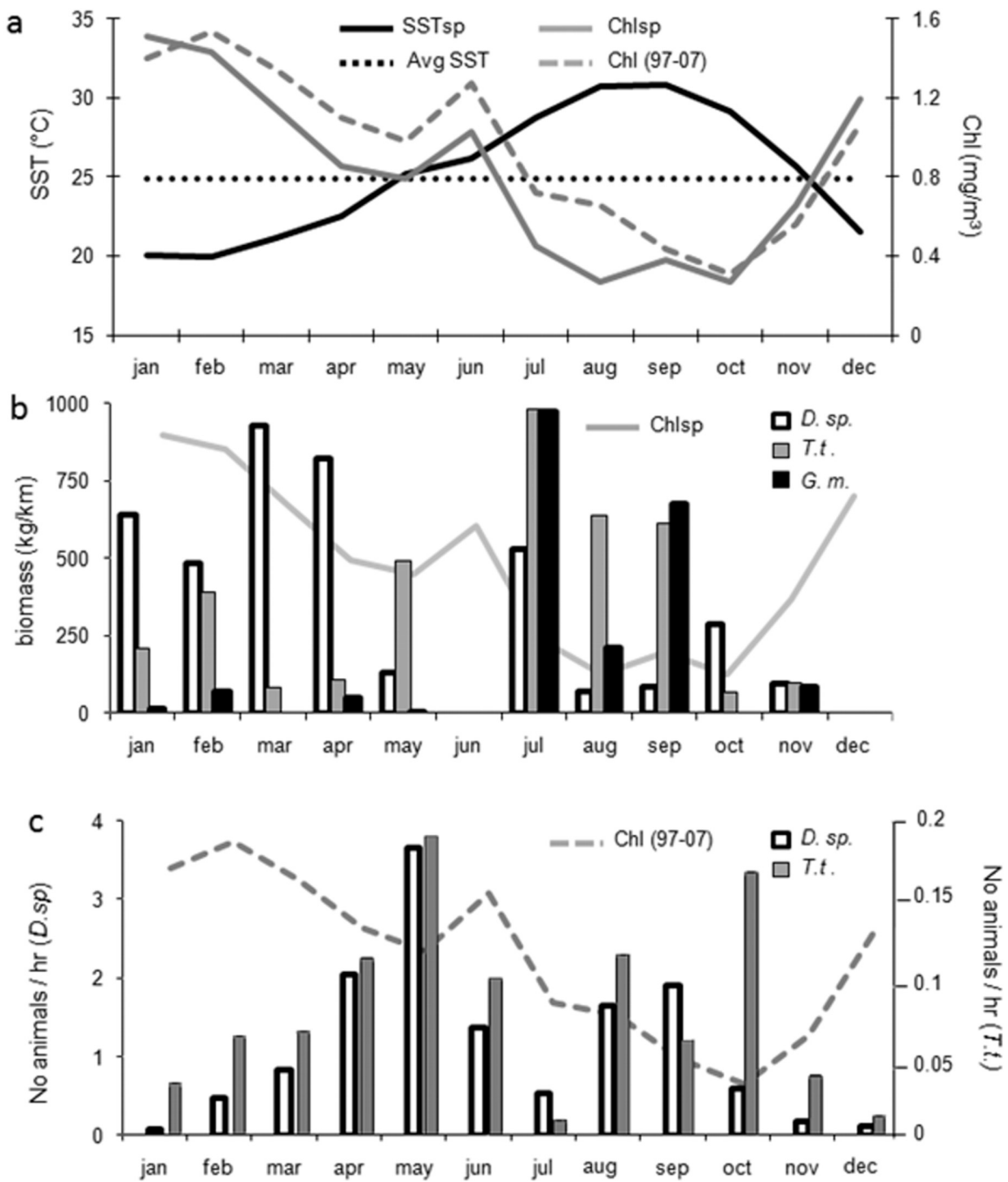

Figure 3. a) Monthly average for the study area and study period of chlorophyll (Chlsp) and sea surface temperature (SSTsp) and monthly average of chlorophyll (Chl) from the 1997-2007 period; b) relative abundance of common dolphins (D. sp.), bottlenose dolphins (T.t.) and pilot whales (G.m.) for this study; c) monthly changes in relative abundance of common dolphins and bottlenose dolphins extracted and modified from Flores-Ramirez et al., (1996).

Table 2. Taxonomic list of species observed in: a) this study, b) Flores-Ramírez et al. (1996) and c) Alba-Fernández (1997).

\begin{tabular}{lllll}
\hline \hline SPECIES & \multicolumn{1}{c}{ COMMON NAME } & A & B & C \\
\hline \hline Physeter macrocephalus (P.m.) & Sperm whale & X & & X \\
Kogia breviceps (K. sp.) & Pygmy sperm whale (Kogia) & X & & \\
Kogia. sima (K. sp.) & Dwarf sperm whale (Kogia) & X & & $\mathrm{X}$ \\
Delphinus capensis (D.sp.) & Long-beaked common dolphin & $\mathrm{X}$ & $\mathrm{X}$ & $\mathrm{X}$ \\
Delphinus delphis (D.sp.) & Short-beaked common dolphin & $\mathrm{X}$ & & $\mathrm{X}$ \\
Tursiops truncatus (T.t) & Bottlenose dolphin & $\mathrm{X}$ & $\mathrm{X}$ & $\mathrm{X}$ \\
Lagenorhynchus obliquidens (L.o.) & Pacific white-sided dolphin & $\mathrm{X}$ & $\mathrm{X}$ & $\mathrm{X}$ \\
Globicephala macrorhynchus (G.m.) & Short-finned pilot whale & $\mathrm{X}$ & $\mathrm{X}$ & $\mathrm{X}$ \\
Pseudorca crassidens (P.c.) & False killer whale & $\mathrm{X}$ & $\mathrm{X}$ & $\mathrm{X}$ \\
Orcinus orca (O.o) & Killer whale & $\mathrm{X}$ & $\mathrm{X}$ & $\mathrm{X}$ \\
\hline \hline
\end{tabular}


Table 3. Total number of sightings (SN), number of animals (No.), weight ( $\mathrm{kg}$ ) from Reeves et al. (2002) used to calculate species biomass, biomass $(\mathrm{kg})$, numbers of seasons that each species was present $(\mathrm{S})$, Importance Value Index (IVI $=\% \mathrm{SN}+\% \mathrm{No}+\% \mathrm{Biomass}+\% \mathrm{~S})$ and categories of dominance.

\begin{tabular}{|c|c|c|c|c|c|c|c|}
\hline SPECIES & SN & No. & WEIGHT & BIOMASS & S & IVI & CATEGORIES \\
\hline Common dolphins & 107 & 21251 & 150 & 3187650 & 6 & 239.0 & Dominant \\
\hline Bottlenose dolphins & 187 & 7861 & 300 & 2358300 & 6 & 207.3 & \\
\hline Short-finned pilot whales & 18 & 786 & 1300 & 1021800 & 6 & 120.0 & Common \\
\hline Dolphins & 15 & 107 & 225 & 24075 & 6 & 104.9 & \\
\hline Kogias & 15 & 18 & 300 & 5400 & 6 & 104.4 & \\
\hline Sperm whales & 6 & 66 & 24000 & 1584000 & 3 & 70.9 & Scarce \\
\hline Killer whales & 3 & 17 & 3800 & 64600 & 3 & 51.7 & \\
\hline False killer whales & 1 & 65 & 1200 & 78000 & 1 & 18.1 & Rare \\
\hline P. white-sided dolphins & 1 & 30 & 150 & 4500 & 1 & 17.1 & \\
\hline Totals & 353 & 30201 & & 8328325 & 6 & & \\
\hline
\end{tabular}
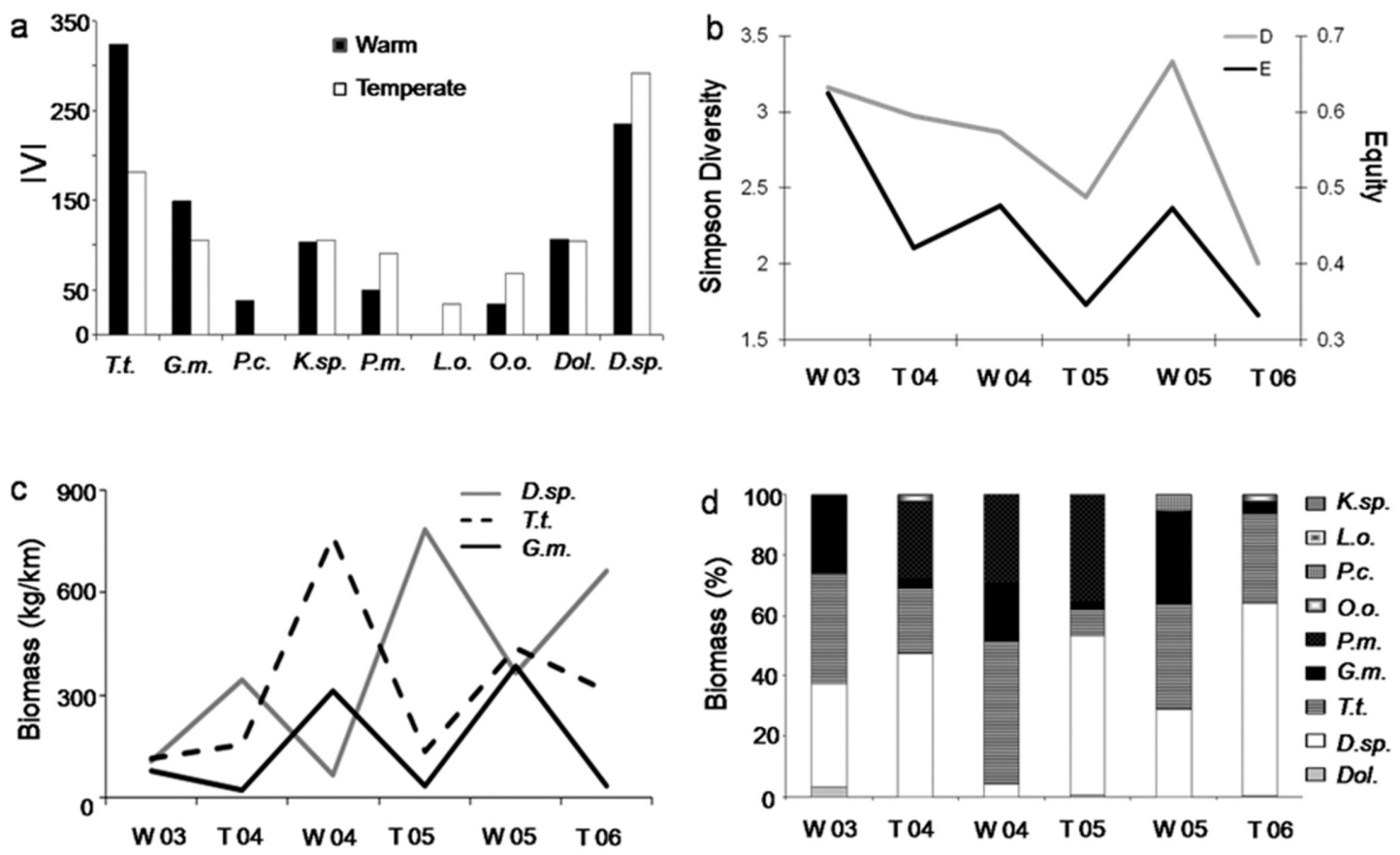

Figure 4. a) seasonal distribution of the relative abundance (biomass); b) seasonal changes of species dominance (Importance Value Index); c) biomass seasonal changes of more dominant species; d) diversity and equity seasonal changes; warm season (W); temperate season (T); common dolphins (D.sp.); bottlenose dolphins (T.t.); short-finned pilot whale (G.m.); kogias (K.sp.); sperm whale (P.m.); killer whale (O.o.); false killer whale (P.c.); Pacific white-sided dolphins (L.o.); dolphins (Dol).

\section{Discussion}

\section{Odontocete community characteristics}

A total of 20 odontocete species have been recorded in La Paz Bay and the adjacent oceanic area (Urbán et al., 1997), 10 more than in the present study (Table 2). However, four species only have one stranding record, and three are known only from one sighting (AlbaFernandez, 1997; Urbán et al., 1997). Previous studies (Flores-Ramírez et al., 1996; Alba-Fernandez, 1997) with similar methodologies have reported six and eight species, respectively (Table 2). These differences with previous studies could be due to: 1 ) observer experience in field species identification, 2) differences in the size of the study area, as previous sampling effort only includes La Paz Bay, while the present study includes a larger area, thus more habitats are available to be exploited by the odontocete community, and 3) differences in the climatic conditions between previous works and the present study (1988-1995 vs. 2003-2006). Therefore, we can say that the community species richness is generally less than 10 and the rest of the 
species are probably occasional visitors that enter into the area during specific oceanographic conditions, possibly related to large-scale environmental variability.

As in previous works in the area, common dolphins and bottlenose dolphins were the dominant species in the community, due to their high relative abundance and persistent occurrence (Table 3). Common dolphins are the most abundant odontocete species inside the GC (Urbán, 1983; Salinas and Bourillon, 1988; Gerrodette and Palacios, 1996) and our results support this. This species was not the most frequently sighted, but it was the most abundant (Table 3) due to their gregarious behavior, which in some cases exceeded the thousands of individuals. Bottlenose dolphins were the most frequently sighted, due to the presence of small local groups of the coastal ecotype, which uses the area throughout the year (Salinas, 2005). Also, both species were identified as an important component in the odontocete community in other areas of the GC like the Ballenas Channel (Tershy et al., 1991), the Bay of Banderas in the southeastern GC (Moncada, 2005) and near the GC mouth in front of the peninsula coast (Troyo-Vega, 2008). The third species in dominance was the pilot whale, then Kogia sp, the first one considered as seasonal visitor to La Paz Bay by Vázquez-Morquecho (1997). As a scarce species we have the sperm whale, although, it is known that sperm whales are more abundant in the central GC, from south of the Midriff Islands to Loreto (Figure 1; Jaquet and Gendron, 2002; Jaquet et al., 2003). The absence of acoustic sampling with a hydrophone may have potentially down-biased the sperm whale data by a factor 3-4 (A. Gannier, pers. comm.).

Finally, and considering studies in adjacent regions to the GC, we can say that the GC odontocete community is similar to other communities reported in different areas of the Eastern Tropical Pacific (Au and Perryman, 1985; Polacheck, 1987; Reilly and Fiedler, 1994; MayCollado et al., 2005; Ballance et al., 2006), including the Galapagos Islands (Smith and Whitehead, 1999; Palacios, 2003). With the exception of oceanic areas where species of the genus Stenella dominate, the common dolphin and bottlenose dolphin are the most frequently observed species, followed by the Risso's dolphin (Grampus griseus) and the short-finned pilot whale. Further to the north, in front of the California Coast, bottlenose dolphins and common dolphins are important components of the odontocete community as well (Bearzi, 2005), while in the oceanic domains of the California Current the most common odontocete species are the Dall's porpoise (Phocoenoides dalli), the Pacific White-sided dolphin and the harbor porpoise (Phocoena phocoena) (Keiper et al., 2005). Based on the above, we can say that the odontocete community in the study area, and in the GC in general, is a temperate-tropical community with affinity to oceanic and coastal waters, which exploits neritic and/or slope areas depending on the geographical features of the region. This community type reflects the environmental characteristics of the GC: marginal and deeper waters located in the temperatetropical transitional zone of the Eastern Pacific.

\section{Temporal community changes}

The temporal lag observed in our results (Figure $3 \mathrm{~b} ; \mathrm{r}=$ 0.77, $p=0.006$ ) and in the Flores-Ramirez et al. (1996) study (Figure 3c), was also documented with bottlenose dolphins in the study area by Salinas (2005), and in an adjacent ecosystem near Magdalena Bay (Figure 1) with several species of marine mammals by Mercuri (2007). This temporal lag between peaks of productivity and the major occurrence of cetaceans is to be expected, because primary producers and odontocete species represent opposite ends of the marine food web. As well, this lag could represent the species movements coupled to the cyclical (seasonal) productivity changes of the environment at a regional scale.

The community structure showed a seasonal dynamism due to changes in dominance and diversity (Figures 4a and $4 \mathrm{~b}$ ) in response to changes in population's numbers (abundance and presence) of the dominant and common species, as well as the presence or absence of scarce and rare species (Figures $4 \mathrm{c}$ and $4 \mathrm{~d}$ ). The Simpson diversity index did not show significant differences between both seasons $(\mathrm{F}=4.359, p=0.105)$. however, it co-varied with the equity index, showing a more diverse and equitable community during the warm season (Figure $4 \mathrm{~b}$ ), consequence of a better distribution of species abundances (Figure 4d). Despite this, major changes were observed in the occurrence of the more dominant species: common dolphins were more abundant during the temperate season, while bottlenose dolphins and short-finned pilot whales were more abundant during the warm season. It has been documented that seasonal and interannual variability in the oceanographic conditions affects the presence and distribution of marine mammals, mediated principally by changes in the abundance and availability of their main prey (Hooker et al., 2002; Lusseau et al., 2004; Keiper et al., 2005; Learmonth et al., 2006). For that reason the seasonal variability in the study area (Figure 3a), as a result of environmental variability in the GC, would be the driver of seasonal changes in the odontocete community, mediated by changes in prey availability within the area.

During the temperate season there was an increase in the occurrence and abundance of common dolphins (Figures $4 \mathrm{a}, 4 \mathrm{c}$, and $4 \mathrm{~d}$ ). The members of this genera generally prey on small schooling fish such as sardines and anchovies (Young and Cockcroft, 1994; Dos Santos and Haimovici, 2001; Reeves et al., 2002; Sanino et al., 2003; Meyner, 2004; Pusineri et al., 2007; Garcia-Gobos et al., 2007), an abundant resource in the study area during this season due to their seasonal movements within GC waters (Lluch-Belda et al., 1986; Hammann et al., 1998). Additionally, during the temperate season, $64 \%$ of sightings with feeding behavior (Table 4) were dominated by common dolphins and $40 \%$ were observed with birds associated like Sula sp., 
Pelecanus occidentalis, Fregata magnificens and Sterna sp. Seabirds are an important component of marine ecosystems and due to their dependence on fish availability, some species are good indicators of fish abundance (Hunt and Schneider, 1987; Cairns, 1987; Velarde et al., 2004). Therefore an increased presence of seabirds associated with odontocete species confirms the idea of a greater abundance of small pelagic fish. Thus, during the temperate and more productive season, a fisheating community dominates inside the area. In contrast, during the warm season this fish-eating community may move to the north, to the nearby Midriff Islands, following the sardines' seasonal movement.

Table 4. Numbers of sightings with feeding behaviors during each season.

\begin{tabular}{lcc}
\hline \hline SPECIES & TEMPERATE & WARM \\
\hline \hline Common dolphins (D.sp.) & 18 & 3 \\
Bottlenose dolphins(T.t.) & 8 & 2 \\
Dolphins & 0 & 1 \\
Killer whales & 1 & 1 \\
Sperm whales + T.t. & 0 & 1 \\
False killer whales + pilot whales (G.m.) + T.t. & 0 & 1 \\
T.t. + G.m. & 0 & 3 \\
T.t. + D.sp. & 1 & 0 \\
\hline Totals sightings with feeding behaviors & 28 & 12 \\
Associated birds (\% of totals) & 40 & 0 \\
\hline \hline
\end{tabular}

During the warm and less productive season we can see an increase in the occurrence and dominance of bottlenose dolphins and short-finned pilot whales (Figure 4a, 4c, and $4 \mathrm{~d})$. The predominance of these species has also been observed by Flores-Ramirez et al. (1996), Alba-Fernandez (1997) and Vázquez-Morquecho (1997) in the La Paz Bay area. In the case of bottlenose dolphins, the two ecotypes have been identified within the study area: the coastal form, with local populations living in La Paz Bay through the year, and the oceanic form identified as groups in transit (Salinas, 2005). Therefore, an increased presence of bottlenose dolphins during the warm season (Figure 4c) could be the reflection of an entry of the oceanic form into the study area. Short-finned pilot whales and oceanic bottlenose dolphins are both known to feed mainly on squid (Clarke, 1996; Walker et al., 1999, Reeves et al., 2002; Díaz-Gamboa, 2003; Gannon and Waples, 2004). Thus, the increased presence of both species matches with the increased presence and aggregation of the jumbo squid in the study area, resulting from their seasonal movements within the GC (Klett, 1996; Brito-Castillo et al., 2000, Morales-Bojórquez et al., 2001; Markaida and Sosa-Nishizaki, 2003). Additionally, during the warm season, the $58 \%$ of sightings with feeding behavior (Table 3) are dominated by squid-eating species, like shortfinned pilot whales, sperm whales, false killer whales and bottlenose dolphins (Clarke, 1996; Reeves et al., 2002), with no seabirds associated. Hence, during the warm and less productive season a squid-eating community dominates inside the area. It is possible that during the temperate season, this squid-eating community moves to the eastern GC coast and/or deeper areas of the GC following the squid's seasonal movements.

In conclusion, we can say that the seasonal community structure changed in agreement with the known seasonal movements of potential prey inside the GC, which, in turn, are related to known seasonal environmental variation. The odontocete community is dominated by fish-eating species during the temperate season and by squid-eating species during the warm season.

\section{Acknowledgements}

We acknowledge the Consejo Nacional de Ciencia y Tecnología (CONACyT) and the Programa Institucional de Formación de Investigadores from the Instituto Politécnico Nacional (PIFI-IPN) for the scholarships given to C.J.S. We thank Cetacean Society International for a student grant. Thanks also to the Marine Mammal Laboratory (UABCS) for the odontocete sighting data, the Ecology Project International (campus La Paz) for their support of the 2006 field trips, respectively, M. Mercuri and G. de la Cruz-Aguero for comments, A. Gedissman for reviewing the English, B. Shirasago and E. Gonzales-Rodríguez (Lalo) for help with the satellite imagery, and reviewers J. C. Herrera-Carmona, S. Siciliano and A. Gannier for helping us to improve the paper with their comments.

\section{References}

Alba Fernández, C.L. (1997) Estructura comunitaria de los odontocetos de Bahía de La Paz y alrededores, B. C. S. México. (mayo de 1989 a abril de 1995). Ba. Thesis. Universidad Autónoma de Baja California Sur. La Paz, B.C.S., México. 66 pp.

Au, D.W.K. and Perryman, W.L. (1985) Dolphin habitats in the eastern tropical Pacific. Fishery Bulletin 83: 623-643.

Ballance, L.T., Pitman, R.L. And Fiedler, P.C. (2006) Oceanographic influences on seabirds and cetaceans of the eastern tropical Pacific: A review. Progress in Oceanography 69: 360-390.

Bearzi, M. (2005) Habitat Partitioning by Three Species of Dolphins in Santa Monica Bay, California. Bulletin of Southern California Academic Science 104(3): 113-124.

Begon, M., Harper, J.L. And Townsend, C.R. (1999) Ecología: individuos, poblaciones y comunidades. Editorial Omega, España.

BEIER, E. (1997) A numerical investigation of the annual variability in the GC of California. Journal of Physical Oceanography. 27(5): 615-632.

BowDITCH, N. (1995) The american practical navigator. National Imagery and Maping Agency. Maryland, USA.

Brito-Castillo, L., Alcántara-Razo, E., Morales-Azpeitia, R. And Salinas-Zavala, C.A. (2000) Temperaturas del Golfo de California durante mayo y junio de 1996 y su relación con las capturas de calamar jumboe (Dosidicus gigas D’Orbigny, 1935). Ciencias Marinas 26(3): 413-440.

CAIRNS, D.K. (1987) Seabirds as indicators of marine food supplies. Biological Oceanography 5: 261-271. 
Clarke, M.R. (1996) The Role of Cephalopods in the World's Oceans. Chephalopods as Prey. III. Cetaceans. Phil. Trans: Biological Science 351(1343): 1053-1065.

Díaz-Gamboa, R. (2003) Diferenciación entre Tursiops truncatus costeros y oceánicos en el Golfo de California por medio de isótopos estables de carbono y nitrógeno. M.Sc. Thesis. Centro Interdisciplinario de Ciencias Marinas - Instituto Politécnico Nacional. La Paz, B.C.S. México. 62 pp.

Dos Santos, R.A. and Haimovici, M. (2001) Cephalopods in the diet of marine mammals stranded or incidentally caught along southeastern and southern Brazil. Fisheries Research 52: 99-112.

Flores-Ramírez, S., Urban, J., Villarreal G., Chávez and VallesJIMÉNES, R. (1996) Cambios espaciales y temporales de la estructura comunitaria de los cetáceos en Bahía de La Paz, B.C.S., México. Ciencias Marinas 22(2): 151-173.

Gannon D.P. and Waples D.M. (2004) Diet of coastal bottlenose dolphins from the U.S. mid-Atlantic coast differ by habitat. Marine Mammals Science 20(3): 527-545.

Garcia-Gobos, I., Van Waerebeek, K., Reyes, J.C., Alfaro-Shigueto, J. And Arias-Schreiber, M. (2007) Prey occurrence in the stomach contents of four small cetacean species in peru. The Latin American Journal of Aquatic Mammals 6(2): 171-183.

Gerrodette, T. and Palacios D.M. (1996) Estimates of cetacean abundance in EEZ waters of the Eastern Tropical Pacific. Administrative Report LJ-96-10. National Marine Fisheries Service, Southwest Fisheries Science Center. La Jolla, California.

Hammann, M.G., Nevárez-Martínez M.O. and Green-Ruíz Y. (1998) Spawning habitat of the Pacific sardine (Sardinops sagax) in the GC of California: Egg and larval distribution 1956-1957 and 1971-1991. California Cooperative Oceanic Fisheries Investigations Reports. 39:169-179.

HOOKer, S.K., WhiteHEAd, H., Gowans, S. AND Baird R.W. (2002) Fluctuations in distribution and patterns of individual range use of northern bottlenose whales. Marine Ecology Progress Series. 225: 287-297.

Hunt G.L. AND SCHNEIDER D.C. (1987) Scale dependent processes in the physical and biological environment of seabirds. Pages 7-41 in Croxall, J.P. (Ed.) The Feeding Ecology of Seabirds and their Role in Marine Ecosystems. Cambridge University Press: Cambridge.

JaQUET N. AND GENDRON D. (2002) Distribution and relative abundance of sperm whales in relation to key environmental features, squid landings and the distribution of other cetacean species in the GC of California, Mexico. Marine Biology 141: 591-601.

Jaquet N., Gendron D. And CoAKes A. (2003) Sperm whales in the GC of California: residency, movements, behavior and the possible influence of the variation in food supply. Marine Mammal Science 19: $545-562$.

Jiménes-Illescas, A.R., Obeso-Nieblas M. and Salas de León. D.A. (1997) Oceanografía física de Bahía de La Paz. in: URBÁn R., J. AND RAMírez R.M. (Eds) La Bahía de la Paz, investigación y conservación. Universidad Autónoma de Baja California Sur / Centro Interdisciplinario de Ciencias Marinas - Instituto Politécnico Nacional / SCRIPPS Institution of Oceanography. México.

Keiper, C.A., Ainley, D.G., Allen, S.G. And Harvey, J.T. (2005) Marine mammal occurrence and ocean climate off central California, 19861994 and 1997-1999. Marine Ecology Progress Series. 289:285-306.

KiszKa, J., Macleod, K., Van Canneyt, O., Walker, D. and Ridoux V. (2007) Distribution, encounter rates, and habitat characteristics of toothed cetaceans in the Bay of Biscay and adjacent waters from platform-of-opportunity data. ICES Journal of Marine Science, 64: 1033-1043.
Klett, A. (1996) Pesquería de calamar jumboe Dosidiscus gigas. Pages 127-151. in: CASAS V. y PONCE D. (Eds) Estudio del potencial pesquero y acuícola de Baja California Sur Vol. 1. Secretaria de Medio Ambiente y Recursos Naturales. México.

KREBS, C.J. (2001) Ecología: estudio de la distribución y la abundancia, $2^{\circ}$ Ed. Oxford University press, México.

Learmonth, J.A., Santos, M.B., Pierce, G.J., Crick, H.Q.P. and RoBinson R.A. (2006) Potential effects of climate change on marine mammals. Oceanography and Marine Biology: An Annual Review, 44: 431-464.

Lusseau, D., Willians, R., Wilson, B., Grellier, K., Hammond, P.S. And Thompson P.M. (2004) Parallel influence of climate on the behaviour of Pacific killer whales and Atlantic bottlenose dolphins. Ecology Letters 7: 1068-1076.

Lluch- Belda, D., Magallón F.J. and Schwartzlose R.A. (1986) Large fluctuations in the sardine fishery in the GC of California: Possible causes. California Cooperative Oceanic Fisheries Investigations Reports 27: 136-140.

Lluch-Belda, D., Arvizu, M.J., Hernández-VÁzquez, S., LLuch-Cota, D., Salinas, A.C.Z., Baumgartner, T., Hammann, G., Cota, V.A., Cotero, C.E., García, F.W., Pedrín, O., Lizárraga, S.M., Martínez, M.A., Morales, R., Nevárez M.O., Santos M.J., Ochoa B.R., Rodríguez, S.R., Torres V.J.R. And PÁez, B.F. (1995) Atlas Pesquero de México. Pesquerías Relevantes. Secretaría de Pesca/Instituto Nacional de la Pesca / Universidad de Colima. México.

Lluch-Cota, S. (2000) Coastal upwelling in the eastern GC of California. Oceanologica Acta 23(6): 731-140.

Lluch-Cota, S., Aragón-Noriega, E.A., Arreguín-Sánchez, F., Aurioles-Gamboa, D., Bautista-Romero, J., Brusca, R. C., CervantesDuarte, R., Cortés-Altamirano, R., Del-Monte-Luna, P., EsquivelHerrera, A., Fernández, G., Hendrickx , M.E., Hernández-VÁzQuez, S., Herrera-Cervantes, H., Kahru, M., Lavín, M., Lluch-Belda, D., Lluch-Cota, D.B. López-Martínez, J., Marinone, S.G., NevárezMartínez, M.O., Ortega-García, S., Palacios-Castro, E., ParésSierra, E., Ponce-Díaz, G., Ramírez-Rodríguez, M., Salinas-Zavala, C.A.,. Schwartzlose, R.A. and Sierra-Beltrán, A.P. (2007) The GC of California: Review of ecosystem status and sustainability challenges. Progress in Oceanography 73: 1-26.

Maluf, L.I. (1983) The physical oceanography. in: CASE, T.J. AND CoDy, M.L. (Eds) Island Biogegraphy in the Sea of Cortez. University of California Press, USA.

Markaida, U. AND Sosa-NishizaKi, O. (2003) Food and feeding habits of jumbo squid Dosidicus gigas (Cephalopoda: Ommastrephidae) from the GC of California, Mexico. Journal of Marine Biology Association UK 83: 507-522.

May-Collado, L., Gerrodette, T., Calambokidis, J. Rasmussen, K., and SEREG, I. (2005) Patterns of cetacean sighting distribution in the Pacific Exclusive Economic Zone of Costa Rica based on data collected from 1979-2001. Revista de Biología Tropical 53(1-2): 249-263.

Mercuri, M. (2007) Varamientos de mamíferos en isla Magdalena, B.C.S., México y su relación con factores físicos y biológicos. M.Sc. Thesis, Centro Interdisciplinario de Ciencias Marinas - Instituto Politécnico Nacional. La Paz, B.C.S., México. 107 pp.

MeYNER, L. (2004) Food and feeding ecology of the common dolphin, Delphinus delphis, in the Bay of Biscay: Intraspecific dietary variation and food transfer modelling. M. Sc. Thesis, University of Aberdeen, Aberdeen, UK. 63 pp.

Moncada, C.R. (2005) Cambio espacio temporal de la estructura comunitaria de los cetáceos de Bahía de Banderas, Nayarit-Jalisco, México 1994-1996. Ba. Thesis. Universidad Autónoma de Baja California Sur, La Paz, B.C.S., México. 50 pp. 
Morales-Bojórquez, E., Cisneros-Mata, M.A., Nevarez-Martínez, M.O. And Hernández-Herrera A. (2001) Review of stock assessment and fishery biology of Dosidicus gigas in the GC of California, Mexico. Fisheries Research 54: 83-94.

Muller-Dombois, D. And Ellenberg H. (1974) Aims and methods in vegetation ecology. John Wiley and Sons, New York, USA.

Navarro-Olache, L.F., Lavín, M.F., Alvarez-Sánchez, L.G. and ZIRINO A. (2004) Internal structure of SST features in the central GC of California. Deep-sea Research II 51: 673-687.

Obeso-Nieblas, M. (2003) Variabilidad espacio-temporal de las condiciones oceanográficas de la Bahía de La Paz, B.C.S., México. Ph.D. Thesis, Centro Interdisciplinario de Ciencias Marinas - Instituto Politécnico Nacional. La Paz, B.C.S., México. 337 pp.

Palacios, D.M. (2003) Oceanographic Conditions Around the Galápagos Archipelago and Their Influence on Cetacean Community Structure. Ph.D. Thesis, Oregon State University, Corvallis, Oregon, USA, 178pp.

POLACHECK, T. (1987) Relative abundance, distribution and interspecific relationship of cetacean schools in the eastern troopical Pacific. Marine Mammal Science 3 (1): 54-77.

Pusineri, C., Magnin, V., Meynier, L., Spitz, J., Hassani, S. And Ridouxi V. (2007) Food and feeding ecology of the common dolphin (Delphinus delphis) in the oceanic northeast Atlantic and comparison with diet in neritic areas. Marine Mammal Science 23(1): 30-47.

Reeves, R.R., Stewart, B., Clapham, P.J. And Powell J.A. (2002) Guide to marine mammals of the world. Knof, USA.

ReIlly, S.B. AND Fiedler P.C. (1994) Interannual variability of dolphin habitats in the eastern tropical Pacific. I: Research vessel surveys, 1986-1990. Fishery Bulletin 92: 434-450.

SAlinas, Z.M. (2005) Ecología de los tursiones, Tursiops truncatus, en la Bahía de La Paz, B.C.S. Ph.D. Thesis. Centro Interdisciplinario de Ciencias Marinas - Instituto Politécnico Nacional. La Paz, B.C.S., México. 102 pp.

Salinas Z.M. and Bourillón M. (1988) Taxonomía, diversidad y distribución de los cetáceos de la bahía de Banderas, México. Ba. Thesis. Facultad de Ciencias, Universidad Nacional Autónoma de México. México D.F. 211 pp.

Sanino, G.P., Van Waerebeek, K. and Yañez. J. (2003) Revisión de la distribución del género Delphinus y registros documentados de Delphinus capensis, en Chile. Boletín del Museo Nacional de Historia Natural, Chile, 52: 97-102.

Santamaria del Angel, E., Alvarez-Borrego, S. And Muller-Karger, F.E. (1994) Gulf of California biogeographic regions based on coastal zone color scanner imagery Geophysical Research 99(4): 7411-7421.

SMITH S.D. AND WhiteHEAd H. (1999) Distribution of dolphins in Galapagos waters. Marine Mammal Science 15: 550-555.

Soto-Mardones, L., Marinone S.G. And Parés-Sierra, A. (1999) Variabilidad espacio-temporal de la temperatura superficial del mar en el Golfo de California. Ciencias Marinas 25(1): 1-30.

Tershy, B.R., Breese, D. And Alvarez-Borrego, S. (1991) Increase in cetacean and seabird numbers in the Canal de Ballenas during an El Nino-Southern Oscillation event. Marine Ecology Progress series 69(3): 299-302.

Troyo-VeGA, V. (2008) Distribución y diversidad de cetáceos en el extremo suroccidental del Golfo de California, 2005. M.Sc. Thesis, Universidad Autónoma de Baja California Sur. La Paz, B.C.S. México.

Urbán, R.J. (1983) Taxonomía y distribución y distribución de los géneros Tursiops, Delphinus y Stenella en las aguas adyacentes Sinaloa y Nayarit, México. Ba. Thesis. Facultad de Ciencias, Universidad Nacional Autónoma de México. México D.F. 86 pp.

Urban, R.J., Gómez-Gallardo, A., Palmeros R.M. and Velásquez, C.G. (1997) Los mamíferos marinos de la Bahía de la Paz, B.C.S. in UrBÁN R.J. And Ramírez R.M. (Eds) La Bahía de la Paz, investigación y conservación. Universidad Autónoma de Baja California Sur / Centro Interdisciplinario de Ciencias Marinas - Instituto Politécnico Nacional / SCRIPPS Institution of Oceanography. México.

Urbán, R.J., Rojas-Bracho L., Guerrero-Ruiz M, Jaramillo-Legorreta A., AND FINDLEY L.T. (2005) Cetacean diversity and conservation in the GC of California. Pages 276-297 in Cartron, J.E., Ceballos, G., AND Felger R.S. (Eds.), Biodiversity, Ecosystems, and Conservation in Northern Mexico. Oxford University Press, New York.

Velarde, E., Ezcurra, E., Cisneros-Mata. M.A. and Lavin M.F. (2004) Seabird ecology, El Niño anomalies, and prediction of sardine fisheries in the GC of California. Ecological Applications, 14(2): 607-615.

VÁZquez-Morquecho, E.I. (1997) Distribución espacio-temporal, fidelidad al área y tamaño poblacional del calderón de aletas cortas Globicephala macrorhynchus (Gray 1846) en la Bahía de La Paz, B.C.S. México (1989-1995). Ba. Thesis. Universidad Autónoma de Baja California Sur. La Paz, B.C.S, México. 66 pp.

Walker, J., Potter C. ANd Macko, S. (1999) The diets of modern and historic bottlenose dolphin populations reflected through stable isotopes. Marine Mammal Science 15(2): 335-350.

Young, D.D. AND CocKCroft, V.G. (1994) Diet of common dolphins (Delphinus delphis) off the south-east coast of southern Africa: Opportunism or specialization. Journal of Zoology 234: 41-53. 